Check for updates

The BMJ

Cite this as: BMJ 2021;372:n258 http://dx.doi.org/10.1136/bmj.n258 Published: 28 January 2021

\title{
Covid-19: Children’s mental health services in England are "nowhere near sufficient," says commissioner
}

\section{Elisabeth Mahase}

The damage to children's mental health caused by the covid-19 pandemic could last for years unless mental health services are improved and expanded, England's children's commissioner has warned. ${ }^{1}$

Anne Longfield said in her annual report that provision of children's mental health services was "still nowhere near sufficient to meet children's needs" and that the government must acknowledge this and "go beyond existing commitments with ambitious new targets to increase access to care."

She also emphasised that some clinical commissioning groups had "consistently deprioritised children's mental health, ignored the needs of children and failed to meet the expectations of NHS England" and as such should now "face consequences."

One in six children in England is estimated to have a probable mental health condition, and the number of children being referred for help is increasing. In 2019-20 this rose to 538564 , an increase of $35 \%$ from 2018-19 and up 60\% from 2017-18.

However, the number of children accessing treatment is not increasing quickly enough to meet the demand. In 2019-20 only 391940 children received treatment-just a quarter of the children estimated to need it. Those that did get access to services often had to wait weeks or months for treatment, and only $20 \%$ of children referred to services started treatment within four weeks.

The report also highlighted that spending on children's mental health was increasing but was too slow, highly variable, and still inadequate despite numerous government announcements. On average, local clinical commissioning group areas spent less than $1 \%$ of their overall budget on children's mental health and 14 times more on adult mental health services.

\section{Impact of covid-19}

Although this report focused on the period before the pandemic took hold (covering March 2019 to March 2020), it found very strong evidence that covid-19 had had a "significantly detrimental impact on some children's mental health."

In July 2020 a large survey commissioned by NHS Digital found that the prevalence of clinically significant mental health conditions among children was $50 \%$ higher than in the previous survey from 2017. While it is not certain how much of the rise was a direct result of the pandemic, previous data from the past 15 years have shown that the rise is normally gradual, suggesting that this significant and rapid increase is a consequence of covid-19.
The report said, "The aspiration in the NHS 10 year plan to provide support to all children who need specialist care by 2028 is very important. This ambition now needs a clear delivery plan to ensure this target is met.

"This will only be achieved if the system of support on offer is broadened out to include support in schools, online and from the voluntary sector."

Longfield has called on the government to now commit to implementing mental health support teams-integrated teams working across schools and the NHS-in every region of England.

1 Children's Commissioner. The state of children's mental health services 2020-21. Jan 2021. https://www.childrenscommissioner.gov.uk/wp-content/uploads/2021/01/cco-the-state-of-childrens-mental-health-services2020-21.pdf.

This article is made freely available for use in accordance with BMJ's website terms and conditions for the duration of the covid-19 pandemic or until otherwise determined by BMJ. You may use, download and print the article for any lawful, non-commercial purpose (including text and data mining) provided that all copyright notices and trade marks are retained. 